\title{
Notes
}

\section{Leaving FISA Behind: The Need To Return to Warrantless Foreign Intelligence Surveillance}

\author{
Nola K. Breglio
}

\section{INTRODUCTION}

In a locked, windowless room with walls of corrugated steel, in a restricted area of a Justice Department building in Washington, sits the Foreign Intelligence Surveillance Court (FISC). Conducting proceedings completely hidden from the public, as mandated by Foreign Intelligence Surveillance Act (FISA) of 1978, the FISC grants government agents permission to surveil targets if there is probable cause to believe they are foreign powers or agents of foreign powers. ${ }^{1}$ The FISC is accustomed to approving each government request it receives, but on May 17, 2002, it issued an order stating that the Department of Justice (DOJ) had overstepped its bounds by promulgating surveillance procedures that gave prosecutors too much supervisory authority over intelligence investigations. $^{2}$ The DOJ insisted that its procedures were in accordance with the FISA amendments passed with the USA PATRIOT Act, ${ }^{3}$ and filed the first ever appeal ${ }^{4}$ to the Foreign Intelligence Surveillance Court of

1. Foreign Intelligence Surveillance Act of $1978 \S 105(\mathrm{a})(3)(A), 50$ U.S.C. $\S 1805(\mathrm{a})(3)(A)$ (2000) (amended 2001).

2. In re All Matters Submitted to the Foreign Intelligence Surveillance Court, 218 F. Supp. 2d 611 (Foreign Intelligence Surveillance Ct.), overruled by In re Sealed Case, 310 F.3d 717 (Foreign Intelligence Surveillance Ct. Review 2002).

3. See Uniting and Strengthening America by Providing Appropriate Tools Required To Intercept and Obstruct Terrorism (USA PATRIOT) Act of 2001, Pub. L. No. 107-56, 115 Stat. 272 (to be codified in scattered sections of $8,12,18,21,22,28,31,47$, and 50 U.S.C.).

4. The appellate procedure in the case was complicated. The Attorney General did not appeal the May 17 FISC decision directly, since that decision did not concern a specific surveillance 
Review, a panel of three senior federal circuit court judges appointed by Chief Justice Rehnquist. The court handed down In re Sealed Case, reversing the FISC order and affirming the legitimacy of the new DOJ procedures and the USA PATRIOT Act amendments. ${ }^{5}$ In late March 2003, the Supreme Court declined to reconsider the decision. ${ }^{6}$

The USA PATRIOT Act has virtually eliminated the specialized intelligence-gathering function of FISA orders; they now can be used with the specific purpose of obtaining evidence to be used in criminal prosecutions, as long as this is not the sole purpose of such investigations.? Additionally, prosecutors and intelligence officials may now consult over FISA warrant application and execution. ${ }^{8}$ A FISA warrant has become little more than a regular Title III warrant ${ }^{9}$ issued secretly with no required showing of probable cause of criminal activity. In view of these significant changes, the FISC retains little unique jurisdiction. The FISC's secret, perfunctory procedures no longer provide constitutionally adequate protection for surveillance targets who will be unknowingly investigated and prosecuted as a direct result of its orders, especially now that FISA surveillance may be used specifically for criminal-and not simply intelligence-gathering-investigations.

The best way to revive the constitutional viability of foreign intelligence surveillance is to forego the FISA warrant procedure entirely and rely on regular Article III courts to guarantee the reasonableness of such searches if challenged. Such a change in process would allow law enforcement authorities more flexibility in pursuing foreign intelligence investigations, since no pre-investigatory warrants would be required, but would also allow for greater protection of the civil liberties of those investigated, since the standard of review would not be simply whether the target is an agent of a foreign power, but whether the search was conducted in a reasonable manner, in conformance with the Supreme Court's Fourth

request. Instead, on July 19, the Attorney General submitted a surveillance application that did not conform with the May 17 FISC order. The FISC, in an order issued the same day, modified this surveillance request according to the May 17 order. The Attorney General then appealed the July 19 modification order, and also appealed an October 17 order modifying the government's application for renewal of the July 19 application. These appeals were then considered jointly by the Foreign Intelligence Surveillance Court of Review. See Sealed Case, 310 F.3d at 729-30.

5. Id. at 719-20.

6. ACLU v. United States, 123 S. Ct. 1615 (2003) (mem.). Since there was no adversary party in the FISC case, the appellate court permitted amicus briefs from the ACLU (in collaboration with the Center for Democracy and Technology, the Center for National Security Studies, the Electronic Privacy Information Center, and the Electronic Frontier Foundation) and the National Association of Criminal Defense Lawyers. See Sealed Case, 310 F.3d at 720. The ACLU then attempted to intervene in the case on behalf of would-be FISA targets and obtain Supreme Court review of the appellate decision, which the Court denied.

7. See USA PATRIOT Act $\S 218$ (to be codified at 50 U.S.C. $\S 1804(\mathrm{a})(7)$ (B)).

8. Id. $\S 504$ (a) (to be codified at 50 U.S.C. $\S 1806(\mathrm{k})$ ).

9. See Omnibus Crime Control and Safe Streets Act of 1968, 18 U.S.C. $\S \S 2510-2522$ (2000). Title III covers federal surveillance operations not related to foreign intelligence. 
Amendment jurisprudence. Warrantless foreign intelligence surveillance would be admissible in criminal prosecutions, but only if such surveillance were determined to be reasonable in post hoc adversary proceedings.

My proposal is not to give the DOJ a blank check to investigate anyone, anytime, anywhere; such a regime would cause the kind of backlash that prompted the passage of FISA in the first place. Rather, if warrantless foreign intelligence surveillance is going to succeed in the twenty-first century, strict executive and legislative branch internal review procedures are necessary. Prosecutors would have to give targets of warrantless operations notice when such investigations are concluded, allowing targets to contest the surveillance in Article III courts. Such a change would benefit all parties involved. The DOJ would enjoy greater freedom in conducting investigations, as it would not have to procure judicial warrants and could act rapidly to investigate time-sensitive threats. At the same time, the entire process would be removed from the supersecret domain of the FISC, making the Attorney General publicly and politically accountable for his orders, allowing targets more opportunities to challenge investigations, and requiring Article III courts to closely examine the constitutionality of warrantless surveillance when targets so desire.

In this Note, I first briefly discuss the reasons for the passage of FISA and the establishment of the FISC, including the past and current workings of the FISC as an institution and its questionable constitutionality even before the USA PATRIOT Act amendments. I then explain how the USA PATRIOT Act and In re Sealed Case have damaged the usefulness and legitimacy of FISA and the FISC. Finally, I make the case for the abolition of FISA and the appropriateness of warrantless searches as the standard in foreign intelligence cases.

\section{FISA AND THE FISC}

\section{A. The Jurisprudential and Political Foundations of FISA}

Much has already been written on the fifty years of jurisprudential and political wrangling leading up to the passage of the Foreign Intelligence Surveillance Act of $1978,{ }^{10}$ but a discussion of the reasoning behind some of the key decisions is necessary to understand the current problems with the system FISA created. The Supreme Court's first definitive ruling on the

10. See, e.g., Americo R. Cinquegrana, The Walls (and Wires) Have Ears: The Background and First Ten Years of the Foreign Intelligence Surveillance Act of 1978, 137 U. PA. L. REV. 793 (1989); Robert A. Dawson, Shifting the Balance: The D.C. Circuit and the Foreign Intelligence Surveillance Act of 1978, 61 GEO. WASH. L. REV. 1380, 1382-87 (1993); Gregory E. Birkenstock, Note, The Foreign Intelligence Surveillance Act and Standards of Probable Cause: An Alternative Analysis, 80 GEO. L.J. 843, 846-49 (1992). 
constitutional legitimacy of wiretapping came in the 1928 case of Olmstead v. United States, in which the Court upheld a warrantless wiretap of defendants' phones that led to the apprehension of a massive liquor bootlegging ring. ${ }^{11}$ The Court refused to construe wiretapping as a search or seizure under the Fourth Amendment, noting that no physical invasion was involved. In explaining its approval of the search, the Court harkened back to what it cited as the "well-known historical purpose of the Fourth Amendment," which was "to prevent the use of governmental force to search a man's house, his person, his papers and his effects[,] . . to prevent their seizure against his will," and to avoid the "misuse of governmental power of compulsion." 12 In the Court's view, the law enforcement action in the case at issue involved no such misuse of power, but rather mere "voluntary conversations secretly overheard." 13 But in the face of political pressure, the Court would soon diverge from this interpretation of the Fourth Amendment.

The Communications Act of 1934 made it illegal to intercept and disclose any wire or radio communication, ${ }^{14}$ and the Supreme Court in Nardone $v$. United States held that, accordingly, such evidence was inadmissible in a criminal prosecution. ${ }^{15}$ But as the specter of World War II became more threatening and a joint congressional resolution authorizing national security wiretapping stalled in the Senate, President Roosevelt acted unilaterally and encouraged Attorney General Robert Jackson to use electronic surveillance when "'grave matters involving defense of the nation"" were involved. ${ }^{16}$ Presidents Truman and Johnson, as well as FBI Director J. Edgar Hoover, continued this practice while retaining the informal limitation on wiretapping to situations involving national security. ${ }^{17}$ According to former Attorney General Edward Levi, between 1940 and 1974, federal agencies authorized approximately 8350 warrantless wiretaps and 2450 warrantless microphone installations. ${ }^{18}$

11. 277 U.S. 438 (1928), overruled by Katz v. United States, 389 U.S. 347 (1967), and Berger v. New York, 388 U.S. 41 (1967).

12. Id. at 463 . For more on this theory of the Warrant Clause, see infra text accompanying notes $162-166$.

13. Olmstead, 277 U.S. at 464.

14. Pub. L. No. $73-416, \S 605,48$ Stat. $1064,1103-04$ (codified as amended at 47 U.S.C. $\S 605(2000))$.

15. 302 U.S. 379 (1937).

16. Cinquegrana, supra note 10, at 798 (quoting Electronic Surveillance Within the United States for Foreign Intelligence Purposes: Hearings on S. 3197 Before the Subcomm. on Intelligence and the Rights of Americans of the Senate Select Comm. on Intelligence, 94th Cong. 24 (1976) [hereinafter Hearings] (statement of Attorney General Edward Levi)).

17. See United States v. Barker, 514 F.2d 208, 243 \& app. at 246 (D.C. Cir. 1975) (MacKinnon, J., dissenting) (describing how warrantless national security searches authorized by the Executive were commonplace until 1972, and appending policy statements of Presidents Roosevelt, Truman, and Johnson to that effect).

18. See Cinquegrana, supra note 10, at 798-99 (citing Hearings, supra note 16, at 25-26 (statement of Attomey General Edward Levi)). 
As the practice became more and more commonplace, the Supreme Court reconsidered the constitutionality of warrantless electronic surveillance in the landmark case of Katz v. United States, where it held that the government's covert microphone surveillance of a telephone booth violated the defendant's Fourth Amendment rights. ${ }^{19}$ The Court did an about-face from Olmstead by holding that even noninvasive, noncompulsory government surveillance could be presumed an unreasonable search. The Katz Court used privacy as its hallmark for constitutional reasonableness, holding that "the Fourth Amendment protects people, not places," and that "what [an individual] seeks to preserve as private, even in an area accessible to the public, may be constitutionally protected." ${ }^{20}$ In the years between Olmstead and Katz, the Court had strengthened its view of the warrant as a necessary constitutional protection for reasonable searches. $^{21}$ The Katz Court accordingly held that warrantless electronic surveillance was per se unreasonable, since its deliberate, pre-arrest nature exempted it from any of the major recognized exceptions to the warrant requirement (searches incident to arrest, hot pursuit, and consent).$^{22}$ But the Court backed away from its seemingly sweeping holding in a footnote at the end of its opinion, where it explicitly noted that it was not ruling on warrantless electronic surveillance when issues of national security were involved. ${ }^{23}$ In a separate concurrence, Justice Douglas strongly objected to the majority's national security exception:

The President and Attorney General are properly interested parties, cast in the role of adversary, in national security cases. They may even be the intended victims of subversive action. Since spies and saboteurs are as entitled to the protection of the Fourth Amendment as suspected gamblers like petitioner, I cannot agree that where spies and saboteurs are involved adequate protection of Fourth Amendment rights is assured when the President and Attorney General assume both the position of adversary-and-prosecutor and disinterested, neutral magistrate. ${ }^{24}$

19. 389 U.S. 347 (1967).

20. Id. at 351-52.

21. See, e.g., Wong Sun v. United States, 371 U.S. 471, $481-82$ (1963); United States v. Jeffers, 342 U.S. 48, 51 (1951). But see United States v. Rabinowitz, 339 U.S. 56, 65-66 (1950) ("It is appropriate to note that the Constitution does not say that the right of the people to be secure in their persons should not be violated without a search warrant if it is practicable for the officers to procure one. The mandate of the Fourth Amendment is that the people shall be secure against unreasonable searches. . . The relevant test is not whether it is reasonable to procure a search warrant, but whether the search was reasonable.").

22. Katz, 389 U.S. at $357-58$.

23. Id. at 358 n. 23 .

24. Id. at 360 (Douglas, J., concurring). 
Though relegated to the sidelines in Katz, the issue of national security surveillance came to a head in United States v. United States District Court, known as the Keith case, where the Court concluded that the government's warrantless electronic surveillance of the target, who was accused of bombing a CIA office, violated his Fourth Amendment rights even though the surveillance was conducted as a result of national security concerns. ${ }^{25}$ Citing Justice Douglas's Katz concurrence, the Court held that executive branch authorities were required to obtain warrants prior to conducting electronic surveillance operations, even for national security purposes. ${ }^{26}$

Just as the Katz Court shied away from the issue of national security surveillance, the Keith Court twice explicitly acknowledged that its insistence on warrants in national security cases only applied to domestic, and not foreign, intelligence surveillance. ${ }^{27}$ In a somewhat cryptic passage that would later be cited by courts considering the constitutionality of FISA, the Court urged Congress to consider the issue of intelligence surveillance with these precepts in mind:

\section{Different standards may be compatible with the Fourth Amendment} if they are reasonable both in relation to the legitimate need of Government for intelligence information and the protected rights of our citizens. For the warrant application may vary according to the governmental interest to be enforced and the nature of citizen rights deserving protection. ${ }^{28}$

Notwithstanding this suggestion that warrantless surveillance might be appropriate in some contexts, the Court's overall refusal to decide the issue of foreign intelligence surveillance led to conflict among the circuit courts-conflict that the Court has not resolved to this day. In the years between Keith and the passage of FISA, the Third, ${ }^{29}$ Fourth, ${ }^{30}$ Fifth, ${ }^{31}$ and

25. 407 U.S. 297 (1972).

26. Id. at 317 ("The historical judgment, which the Fourth Amendment accepts, is that unreviewed executive discretion may yield too readily to pressures to obtain incriminating evidence and overlook potential invasions of privacy and protected speech.").

27. Id. at 308-09 \& n.8, 321-22.

28. Id. at 322-23.

29. See United States v. Butenko, 494 F.2d 593, 608 (3d Cir. 1974) (noting that the President "must be aware of the posture of foreign nations toward the United States, the intelligence activities of foreign countries aimed at uncovering American secrets, and the policy positions of foreign states on a broad range of international issues," and that any searches for this information were thus not "unreasonable," despite the possibility that the privacy of alien officials, agents, and even American citizens might be infringed).

30. See United States v. Truong Dinh Hung, 629 F.2d 908, 913-16 (4th Cir. 1980).

31. See United States v. Brown, 484 F.2d 418, 426 (5th Cir. 1973) ("[B]ecause of the President's constitutional duty to act for the United States in the field of foreign relations, and his inherent power to protect national security in the context of foreign affairs, we reaffirm ... that the President may constitutionally authorize warrantless wiretaps for the purpose of gathering foreign intelligence."). 
Ninth $^{32}$ Circuits all recognized a "foreign intelligence exception" to the surveillance warrant requirement imposed in Keith. ${ }^{33}$ The circuits that created such an exception used similar reasoning to that elaborated by the Fourth Circuit in United States v. Truong Dinh Hung. Though the Keith Court had deliberately not provided any specific guidance on the issue of foreign intelligence surveillance, the Truong court used the Keith domestic security balancing test to assess the legitimacy of warrantless foreign intelligence searches. Under the Keith test,

If the legitimate need of Government to safeguard domestic security requires the use of electronic surveillance, the question is whether the needs of citizens for privacy and free expression may not be better protected by requiring a warrant before such surveillance is undertaken. We must also ask whether a warrant requirement would unduly frustrate the efforts of Government to protect itself from acts of subversion and overthrow directed against it. ${ }^{34}$

Applying this formula, the Truong court concluded that the unique nature of foreign intelligence tipped the balance in favor of the government and that Article III courts were not qualified to decide such sensitive political issues. The court feared that the "procedural hurdle" of the warrant requirement might foil attempts "to counter foreign threats to the national security [that] require the utmost stealth, speed, and secrecy." 35 In addition, the court opined that while courts are intimately familiar with the standards of probable cause required for normal criminal warrants, "the judiciary is largely inexperienced in making the delicate and complex decisions that lie behind foreign intelligence surveillance." ${ }^{, 36}$ The court noted that separation of powers concerns led it to conclude that deference to the Commander in Chief in the realm of foreign and military affairs was the most constitutionally appropriate course of conduct. ${ }^{37}$

The Truong court noted, however, that this calculus would necessarily change if and when an investigation transitioned from intelligencegathering to criminal, because "once surveillance becomes primarily a

32. See United States v. Buck, 548 F.2d 871, 875 (9th Cir. 1977) ("Foreign security wiretaps are a recognized exception to the general warrant requirement ....").

33. Notably, the D.C. Circuit twice refused in dicta to acknowledge a separate foreign intelligence exception. First, it held that the exigent circumstances doctrine would adequately cover any emergency foreign intelligence searches. Zweibon v. Mitchell, 516 F.2d 594, 649-50 (D.C. Cir. 1975) (en banc). Later, the court ruled that such an exception would only be acceptable in "instances of immediate and grave peril to the nation." Halperin v. Kissinger, 606 F.2d 1192, 1201 (D.C. Cir. 1979).

34. United States v. United States Dist. Court, 407 U.S. 297, 315 (1972).

35. Truong, 629 F.2d at 913.

36. Id.

37. Id at 914 . 
criminal investigation, the courts are entirely competent to make the usual probable cause determination, and because, importantly, individual privacy interests come to the fore and government foreign policy concerns recede when the government is primarily attempting to form the basis for a criminal prosecution." 38 This precept came to be known as the primary purpose doctrine. Under this formulation, the Truong court held that "the executive should be excused from securing a warrant only when the surveillance is conducted 'primarily' for foreign intelligence reasons." 39

The foreign intelligence exception thus remained a large window for totally unsupervised government surveillance. In the wake of the Watergate scandal, Congress investigated whether it could formalize standards for surveillance operations and crack down on over-intrusive use of warrantless searches. The Senate's Church Committee, formed to study governmental intelligence operations and chaired by Senator Frank Church, found that government agents often had violated both Title III and the Fourth Amendment rights of many citizens by conducting intelligence surveillance without any legitimate basis or suspicion of criminal activity, much less connection with foreign powers. The Committee determined that "the absence of precise standards for intelligence investigations" contributed to this phenomenon. ${ }^{40}$ The Committee concluded, "[N]ow it is time for Congress to turn its attention to legislating restraints upon intelligence activities which may endanger the constitutional rights of Americans. 41

This was exactly what Congress did. After two years of revisions and debates, Congress passed the Foreign Intelligence Surveillance Act of $1978 .^{42}$ The Senate Report on FISA offers evidence that Congress carefully considered the relevant Fourth Amendment jurisprudence in formulating the statute:

The departures here from conventional Fourth Amendment doctrine have ... been given close scrutiny to ensure that the procedures established in [FISA] are reasonable in relation to legitimate foreign counterintelligence requirements and the protected rights of individuals. Their reasonableness depends, in part, upon an assessment of the difficulties of investigating activities planned,

38. Id. at 915 .

39. Id.

40. 2 SELECT COMM. TO STUdY GOVERNMENTAL OPERATIONS, FINAL REPORT OF THE SENATE SElect COMM. TO STUDY GOVERnMENTAL OPERATIONS WITH RESPECT TO INTELLIGENCE ACTIVITIES: INTELLIGENCE ACTIVITIES AND THE RIGHTS OF AMERICANS, S. REP. No. 94-755, at 165 (1976).

41. Id. at 289.

42. Pub. L. No. 95-511, 92 Stat. 1783. For more details on the passage of FISA, see Cinquegrana, supra note 10, at 806-12. 
directed, and supported from abroad by foreign intelligence services and foreign-based terrorist groups.

FISA was intended to provide the executive branch with judicial supervision over its foreign intelligence surveillance operations that would preserve the civil liberties of those being investigated, while at the same time accommodating the flexibility, secrecy, and executive discretion that the courts had noted was necessary in military and foreign affairs. It is an imaginative and hybrid statute that designs an entirely new procedure for procuring judicial authorization. Upon the foreign surveillance application of a government agent, one of eleven FISC judges ${ }^{44}$ must determine whether or not there is probable cause to believe that the target of the surveillance is a "foreign power or an agent of a foreign power." persons are involved, then the evidence submitted by the government must not rest solely on First Amendment-protected conduct or speech. ${ }^{46}$ The court may not approve the surveillance unless the government proposes sufficiently strict minimization procedures to prevent the use or distribution of intercepted intelligence concerning U.S. persons. ${ }^{47}$ The FISC judge does not conduct the same kind of probable cause analysis that a normal Article III judge would; he or she simply must determine if the FISA requirements are met, and if they are, the warrant must be issued. ${ }^{48}$ Thus the government need not delve into the nature of the suspected criminal activity, as with a normal criminal warrant. The main tasks are proving compliance with the statutory framework and proving the identity of the target. This less stringent probable cause standard dovetails with the Supreme Court's jurisprudence on the issue, which, as we have seen, also turns on the foreign-domestic distinction and the importance of executive discretion in the realm of foreign affairs. ${ }^{49}$

43. SELECT COMM. ON INTELligenCE, Foreign INTELligenCE SURVEILlaNCE ACT OF 1978, S. REP. NO. 95-701, at 14 (1978), reprinted in 1978 U.S.C.C.A.N. 3973, 3983 [hereinafter S. REP. No. 95-701].

44. All eleven FISC judges also serve as federal district court judges. For the first twenty-five years of its existence, the FISC had seven judges. The USA PATRIOT Act amended FISA to provide for four additional judges on the court. USA PATRIOT Act, Pub. L. No. 107-56, § 208, 115 Stat. 272, 283 (2001) (to be codified at 50 U.S.C. $\$ 1803(\mathrm{a})$ ).

45. 50 U.S.C. $\S 1805(\mathrm{a})(3)(\mathrm{A})(2000)$.

46. Id.

47. Id. $\S \S 1801(\mathrm{~h}), 1805(\mathrm{a})(4)$.

48. Id. $\S 1805(\mathrm{a})$.

49. There are two exceptions to the requirement of FISC authorization: (1) The Attorney General may surveil communications without FISC authorization if such communications are exclusively between or among foreign powers, or pertain to technical intelligence under the control of a foreign power, Id. $\S 1802$; and (2) in an emergency situation, the Attorney General may surveil any foreign intelligence communications for seventy-two hours before getting FISC approval, see Intelligence Authorization Act for Fiscal Year 2002, Pub. L. No. 107-108, § 314(a)(2)(B), 115 Stat. 1394, 1402 (2001) (to be codified at 50 U.S.C. $§ 1805(f)$ ). 
After FISA's passage, judicial attention to the foreign intelligence surveillance issue tapered off, as the courts trusted that the new statutory framework would provide the necessary standards. The Truong court acknowledged in a footnote that the "elaborate structure of [FISA] demonstrates that the political branches need great flexibility to reach the compromises and formulate the standards which will govern foreign intelligence surveillance," and that as such, this was an area of the law from which the courts would do best to shy away. ${ }^{50}$ FISA thus became the primary mechanism for policing executive discretion in foreign intelligence surveillance operations.

\section{B. The Workings-and Failings - of the FISC}

The FISC is the centerpiece of FISA. Because of its hidden procedures and attenuated probable cause standard, the surveillance court has been called "the strangest creation in the history of the federal Judiciary." 51 The FISC's judges are charged with striking the delicate balance between foreign policy and civil liberties; since the court operates behind a veil of secrecy, it is almost impossible to assess their effectiveness in this role. What little information is available might lead some to conclude that the FISC has never been in the business of balancing. According to officials at the Office of Intelligence Policy and Review, as of July 2001, the FISC had never denied a search or surveillance request. ${ }^{52}$ Indeed, that perfect record remains intact, as the FISC's controversial order in 2002 simply modified the government's request instead of denying it altogether. ${ }^{53}$ This is remarkable given that in its first twenty-three years of existence, the FISC considered more than 16,000 applications. $^{54}$

It is important to note, however, that the government has had similar success in the granting of its applications for warrants under Title III:

50. United States v. Truong Dinh Hung, 629 F.2d 908, 914 n.4 (4th Cir. 1980). Though FISA had not been passed at the time the surveillance in Truong was conducted, it was in effect by the time of the decision.

51. James Bamford, The Puzzle Palace: a Report on america's Most Secret AGENCY 368 (1982). Bamford describes the FISC as "the product of compromises between legislators who wanted the NSA and FBI, the only agencies affected by the FISA, to follow the standard procedure of obtaining a court order required in criminal investigations, and legislators who felt the agencies should have no regulation whatsoever in their foreign intelligence surveillances." Id.

52. U.S. GEN. ACCOUNTING OFFICE, FBI INTELLIGENCE INVESTIGATIONS: COORDINATION WITHIN JUSTICE ON COUNTERINTELLIGENCE CRIMINAL MATTERS IS LIMITED 3 (2001).

53. See In re All Matters Submitted to the Foreign Intelligence Surveillance Court, $218 \mathrm{~F}$. Supp. 2d 61 1, 626-27 (Foreign Intelligence Surveillance Ct.), overruled by In re Sealed Case, 310 F.3d 717 (Foreign Intelligence Surveillance Ct. Review 2002).

54. For statistics dating from the FISC's inception, see Elec. Privacy Information Ctr., Foreign Intelligence Surveillance Act Orders 1979-2002 (May 6, 2003), at http://www.epic.org/privacy/wiretap/stats/fisa_stats.html. 
Between 1992 and 2002, courts denied just four out of the more than 13,000 Title III wiretap applications they received. ${ }^{55}$ The FISC is thus not unique in its consistent approval of government surveillance applications. Royce Lamberth, the former Chief Judge of the FISC, publicly attributed the government's perfect record in the FISC to the "superb internal review process created within the Department of Justice," 56 which requires personal approval of the Attorney General and the head of the requesting agency on each FISA application, and often results in the submission of forty- to fifty-page government affidavits to FISC judges. ${ }^{57}$ Indeed, according to agency insiders, roughly three-quarters of surveillance requests are initially refused by internal government review processes and subsequently resubmitted. ${ }^{58}$ Lamberth also noted that numerous requests made to the FISC are revised or withdrawn and resubmitted before approval, and that no district or appellate court had ever reversed a FISA order granted by the FISC. ${ }^{59}$ James Comey, the United States Attorney for the Southern District of New York, has stated that it is a misconception that the standards for obtaining FISA warrants are lower. ${ }^{60}$ In most cases, according to Comey, it is easier to establish that a target is involved in criminal activity than to prove that the target is an agent of a terrorist organization. The review process for FISA warrants at DOJ is "something above probable cause," just as it is for Title III warrants, because the government does not want to lose credibility with the courts and submit applications that are not well supported. ${ }^{61}$

Even if the internal controls on the submission of FISA applications are as tight as government officials and judges say they are, the FISC's secret procedures generate other significant problems. Appealing a FISC surveillance order is virtually impossible in the current system since a defendant might never know such an order had existed in his case or what proof the government had submitted in support of it. For security reasons,

55. ADMIN. OFFICE OF THE U.S. COURTS, REPORT OF THE DIRECTOR OF THE ADMINISTRATIVE OFFICE OF THE U.S. COURTS ON APPLICATIONS FOR ORDERS AUTHORIZING OR APPROVING THE INTERCEPTION OF WIRE, ORAL, OR ELECTRONIC COMMUNICATIONS $30 \mathrm{tbl.7}$ (2003), at http://www.uscourts.gov/wiretap02/table7-02.pdf.

56. Benjamin Wittes, The FISA Court Speaks, LeGAL TIMES, Feb. 19, 1996, at 21.

57. An Interview with Judge Royce C. Lamberth, THIRD BRANCH (Admin. Office of the U.S. Courts, Washington, D.C.), June 2002, at http://www.uscourts.gov/ttb/june02ttb/interview.html.

58. Benjamin Wittes, Inside America's Most Secretive Court, LEGAL TIMES, Feb. 19, 1996, at 22 .

59. Intelligence on the FISA Court, LEGAL TIMES, Apr. 14, 1997, at 18 ("I have pen-andinked changes myself on the things. I have had things revised and resubmitted. I know other judges have done the same, and these don't count as denials. We could probably, if we wanted to play some games, create denials and then reapplications and grant those, and you know, play numbers games. ... We've just never done that.").

60. James Comey, Address to the Yale Law School Federal Criminal Investigations Class (Apr. 25, 2003) [hereinafter Comey Address].

61. Id. 
defense attorneys typically are not allowed to inspect FISA applications (although district court judges have some discretion in this regard). ${ }^{62}$ The FISC is listed in neither The United States Government Manual nor The United States Court Directory. Its proceedings are closed to the public; even its location was initially kept secret, and the path through a number of cipher-locked doors to enter the courtroom has been likened to something out of Get Smart. ${ }^{63}$ The court holds almost no adversary hearings and issues extraordinarily few public opinions or reports. ${ }^{64}$ Some have argued that if more people knew about the FISC, there would be an uproar about its seemingly antidemocratic procedures. ${ }^{65}$ One former National Security Administration staff member who observed the FISC for several years in the mid-1990s (and later became a defense attorney) stated in 1996 that FISC procedures were wholly lacking in legal formalities, and remarked, "There is little question that these judges exercise virtually no judicial review." ${ }^{" 66}$ It is unclear whether or not the FISC provides a genuine check on applications for foreign intelligence surveillance, given that even Judge Lamberth has acknowledged that the most extensive scrutiny of FISA requests occurs within the Justice Department. It could be argued that the FISC's primary role is not to exercise judgment in each individual case, but to put a judicial imprimatur on each executive branch request it receives that comports with FISA's statutory requirements-an inappropriate and perhaps unconstitutional role for any Article III court. ${ }^{67}$

Indeed, numerous litigants have challenged the constitutionality of FISA itself. The first major Fourth Amendment challenge to FISA surveillance came in United States v. Duggan, where the Second Circuit held that even though government agents are not required to show probable cause of criminal activity to obtain warrants, FISA procedures as set forth by Congress are a "constitutionally adequate balancing of the individual's

62. See Foreign Intelligence Surveillance Act of 1978, 50 U.S.C. $\S 1806(f)(2000)$. This issue has come up in the recent case of United States v. Battle, No. 3:02cr399 (D. Or. filed Oct. 3, 2002), where five accused terrorists have demanded and been denied access to the government applications for FISA warrants used to obtain intelligence information that will be used against them at trial. See Anita Ramasastry, Recent Oregon Ruling on Secret Warrants May Set Troublesome Precedent, CNN, Mar. 18, 2003, at http://www.cnn.com/2003/LAW/03/18/ findlaw.analysis.ramasastry.warrant/index.html.

63. See Wittes, supra note 58 , at 22.

64. See BAMFORD, supra note 51 , at 370 .

65. See Gerald H. Robinson, We're Listening! Electronic Eavesdropping, FISA, and the Secret Court, 36 WILlAMETTE L. REV. 51, 74 (2000); Dahlia Lithwick, Secrets and Lies: SeventyFive Little Reasons To Be Terrified of the FISA Court, SLATE, Aug. 29, 2002, at http://slate.msn.com/id/2070287.

66. Wittes, supra note 58 , at 1 .

67. See infra Section III.A. 
Fourth Amendment rights against the nation's need to obtain foreign intelligence information." 68

Litigants have also filed Fifth Amendment due process claims in criminal cases resulting from FISA-obtained information. Along with other courts, the D.C. Circuit upheld the constitutionality of secret, ex parte FISC proceedings in United States $v$. Belfield, noting that in FISA, as opposed to Title III, Congress had emphasized the "need for the Executive to engage in and employ the fruits of clandestine surveillance without being constantly hamstrung by disclosure requirements." 69 The court also noted the importance of in camera review of FISC applications in the delicate realm of foreign intelligence surveillance, and the tradition throughout the circuits of foregoing adversary hearings on such sensitive evidence in favor of national security interests. ${ }^{70}$

First Amendment challenges to FISA have been few and unsuccessful ${ }^{71}$ because of the explicit recognition in the statute that United States persons may not be deemed agents of a foreign power solely on the basis of First Amendment-protected conduct. ${ }^{72}$

Courts have summarily rejected other, more minor constitutional challenges to FISA. Despite the fact that its judges sit for nonrenewable seven-year terms, courts have affirmed the FISC's status as an Article III court; since all of its judges are also federal district judges with life tenure and fixed salaries, their term limits have not been determined to materially affect the legitimacy of the FISC. ${ }^{73}$ Defendants have also alleged that FISC judges are required to consider political questions when determining whether or not to grant FISA orders. The Duggan court rejected this claim by holding that the decisions involved in FISA applications are carefully defined in the statute and are no different from the many "sindings of

68. 743 F.2d 59, 73 (2d Cir. 1984), aff'g United States v. Megahey, 553 F. Supp. 1180, 1185 89 (E.D.N.Y. 1982) (pointing out that before FISA, the consensus among circuit courts was that no warrant at all was required for foreign intelligence searches); see also In re Kevork, $634 \mathrm{~F}$. Supp. 1002, 1010-13 (C.D. Cal. 1985) (noting the distinction set forth in Keith and in the legislative history of FISA between ordinary criminal surveillance and foreign intelligence surveillance), aff'd, 788 F.2d 566 (9th Cir. 1986); United States v. Falvey, 540 F. Supp. 1306, 1311 (E.D.N.Y. 1982) (stating that three circuit courts have held that no warrant was required for foreign intelligence searches).

69. 692 F.2d 141, 148 (D.C. Cir. 1982)

70. Id. at 149; see also Foreign Intelligence Surveillance Act of $1978 \S 106(\mathrm{f}), 50$ U.S.C. $\S 1806$ (f) (2000) (providing that where a defendant moves to discover or obtain information uncovered through FISA surveillance, the court may suppress such evidence "if the Attorney General files an affidavit under oath that disclosure or an adversary hearing would harm the national security of the United States").

71. See, e.g., Falvey, 540 F. Supp. at 1314-15.

72. 50 U.S.C. $\$ 1805(\mathrm{a})(3)(\mathrm{A})$.

73. See United States v. Cavanagh, 807 F.2d 787, $791-92$ (9th Cir. 1987); Megahey, 553 F. Supp. at 1197 . 
objective fact" made in district courts. ${ }^{74}$ Another, perhaps more salient objection has been that the FISC violates separation of powers, in that it functions in many ways as an arm of government agencies and the DOJ; sworn to secrecy, sitting in a DOJ building, and ruling solely on government documents with no adversary party, the FISC appears to have less judicial independence than other Article III courts. ${ }^{75}$ But reviewing courts have dismissed this claim out of hand, holding that the FISC "retains all the inherent powers that any court has when considering a warrant."76 Lastly, the USA PATRIOT Act made several changes to FISA that may be considered unconstitutional. The most significant of these is considered in Part II.

\section{Breaking Down the Wall}

Before considering the necessity and legitimacy of the USA PATRIOT Act amendments to FISA, it is important to assess the effectiveness of the pre-USA PATRIOT Act FISA regime, and to determine whether it was successful in its mission of helping law enforcement authorities prevent foreign attacks against the United States while preserving the civil liberties of surveillance targets. On the positive side, there is ample evidence that FISA has led federal investigators to significant victories in the apprehension of terrorists, even before the USA PATRIOT Act amendments were passed. FISA surveillance was used in the detection of those responsible for the 1993 World Trade Center bombings; in that case, now-Chief Judge Mukasey held that such evidence was admissible as the fruit of legitimately certified intelligence surveillance. ${ }^{77}$ Similarly, FISA surveillance has been used to convict conspirators passing U.S. secrets on to foreign nations, ${ }^{78}$ and to detect numerous international terrorist rings. ${ }^{79}$

74. United States v. Duggan, 743 F.2d 59, 74 (2d Cir. 1984) (quoting Megahey, 553 F. Supp. at 1196). Applying the factors set forth in Baker v. Carr, 369 U.S. 186 (1962), the Megahey court concluded that FISA does not require courts to involve themselves in political questions. Megahey, 553 F. Supp. at 1197-98.

75. See Robinson, supra note 65, at 69.

76. See, e.g., In re Kevork, 634 F. Supp. 1002, 1014 (C.D. Cal. 1985), aff'd, 788 F.2d 566 (9th Cir. 1986). But see infra Section III.A (describing how any court's consideration of a surveillance request might violate the Constitution's case or controversy requirement).

77. United States v. Rahman, 861 F. Supp. 247, 251 (S.D.N.Y. 1994), aff'd, 189 F.3d 88 (2d Cir. 1999).

78. See, e.g., United States v. Squillacote, 221 F.3d 542 (4th Cir. 2000) (East Germany); United States v. Pelton, 835 F.2d 1067 (4th Cir. 1987) (Soviet Union); Cavanagh, 807 F.2d 787 (same).

79. See, e.g., Duggan, 743 F.2d 59 (upholding the use of FISA to apprehend members of the Irish Republican Army transporting explosives from the United States to Ireland for use against the British Army); Global Relief Found., Inc. v. O'Neill, 207 F. Supp. 2d 779 (N.D. Ill.) (upholding the use of FISA to freeze the assets and property of organizations suspected of terrorist ties), aff'd, 315 F.3d 748 (7th Cir. 2002), petition for cert. filed, 72 U.S.L.W. 3092 (U.S. July 3, 2003) (No. 03-46). 
But many law enforcement authorities argued that the pre-USA PATRIOT Act FISA imposed restraints on the executive branch, forcing investigators to jump through too many hoops in an area where their discretion should be virtually unfettered. Much of this difficulty was caused by the primary purpose doctrine, first established by the Truong court, which restricted the use of FISA to operations conducted primarily for intelligence-gathering purposes and established a "wall" preventing communication between those conducting criminal investigations and those gathering intelligence. The wall procedures were followed informally from FISA's inception, were formally adopted by the DOJ in 1995, and were required as a FISC rule of procedure starting in early $2001 .^{80}$

But in a report on FBI intelligence investigations released just two months before the September 11 attacks, the DOJ concluded that the primary purpose and wall procedures had proved detrimental to a number of operations. According to the report, it was common for FBI investigators not "to notify the Criminal Division of possible federal crimes as they feared such contacts could be detrimental should they decide to subsequently seek the use of FISA tools." ${ }^{11}$ The report stated that such concerns had affected FBI and Criminal Division cooperation in both the FBI's investigation of the Los Alamos National Laboratory and the Aldrich Ames espionage case. ${ }^{82}$ One commentator with experience in military affairs remarked that FISA's "extraordinary procedures and high standards of proof result in unnecessary investigatory delay, if not a bar" to important intelligence investigations. ${ }^{83}$

As times changed, the rigid FISA wall procedures became more unworkable. James Comey recently noted that when FISA was enacted, during the Cold War, primary surveillance targets were more easily defined, as they were associated with distinct nations such as the Soviet Union. Comey asserted that the wall procedures are more difficult to follow in today's world, when FISA is primarily being used to prevent international terrorism and detect amorphous, sprawling organizations with operatives from all parts of the globe. ${ }^{84}$ Comey described a somewhat absurd result that the FISA wall brought about: Often different government agencies would be conducting simultaneous FISA and Title III surveillance of the

80. In re All Matters Submitted to the Foreign Intelligence Surveillance Court, $218 \mathrm{~F}$. Supp. 2d 611, 619-22 (Foreign Intelligence Surveillance Ct.), overruled by In re Sealed Case, 310 F.3d 717 (Foreign Intelligence Surveillance Ct. Review 2002).

81. U.S. GEN. ACCOUNTING OFFICE, supra note 52, at 12.

82. Id. at 11-12; see also David A. Vise \& Vernon Loeb, Justice Study Faults FBI in Spy Case: Wen Ho Lee Probe Too Slow and Sloppy, Report Says, WASH. POST, May 19, 2000, at A1.

83. Gerald F. Reimers II, Foreign Intelligence Surveillance Act, 4 J. NAT'L SECURITY L. 55, 101 (2000) (providing a detailed analysis of the failings of FISA in the Wen Ho Lee case at Los Alamos).

84. Comey Address, supra note 60. 
same target, without each other's knowledge. ${ }^{85}$ Mary Jo White, former U.S. Attorney for the Southern District of New York, agreed, saying that "the single most important thing impeding terrorism investigations was the wall between investigating and prosecuting terrorism." ${ }^{.86}$ White explained that the wall procedures at times could have deprived government agents on the trail of terrorists of valuable information, and in a complex investigation such gaps in communication between different agencies could be fatal: "You've got to put both sides of the Jell-O box together or you don't have a prayer." $" 87$

In her now-famous memo to FBI Director Robert Mueller, FBI Special Agent Coleen Rowley expressed exactly this sort of frustration over the fact that she and her fellow agents had not been able to obtain a FISA warrant to search the contents of Zacarias Moussaoui's computer immediately after it was seized-a search that she intimated would have yielded information that might have prevented the September 11 attacks. ${ }^{88}$ Rowley blamed this course of events on fundamental problems with the FISA system: "[T]he process allowed the Headquarters Supervisor to downplay the significance of the information thus far collected in order to get out of the work of having to see the FISA application through ...." ${ }^{, 89}$ Ironically, Rowley had advised the Moussaoui team to seek a FISA warrant in the first place because, though she believed there was probable cause for a criminal warrant, "there is a common perception... that if the FBI can't do something through straight-up criminal methods, it will then resort to using less-demanding intelligence methods." 90

Rowley paints a picture of a broken system-one where criminal and FISA warrants were used somewhat interchangeably, with agents choosing the latter when they felt they had a weaker case, ${ }^{91}$ but where even the "less-

85. Id.

86. Mary Jo White, Address to the Yale Law School Federal Criminal Investigations Class (Apr. 4, 2003).

87. Id.

88. Memorandum from Coleen M. Rowley, Special Agent and Minneapolis Chief Division Counsel, FBI, to Robert Mueller, Director, FBI (May 21, 2002), http://www.time.com/ time/nation/printout/0,8816,249997,00.html [hereinafter Rowley Memorandum].

89. Id. para. 10; see also David Johnston \& Philip Shenon, F.B.I. Curbed Scrutiny of Man Now a Suspect in the Attacks, N.Y. TIMES, Oct. 6, 2001, at Al (citing a confidential source that explained that the DOJ did not seek a FISA warrant in the Moussaoui case because "the bureau and the Justice Department were under pressure from the chief judge on the [FISC] who had questioned whether the government was being candid when it sought approval for intelligence surveillance against people who were already the subjects of criminal investigations").

90. Rowley Memorandum, supra note 88, para. 7.

91. Federal government statistics indicate that in recent years, the number of criminal warrants has declined, while the number of FISA warrants has increased. See Kevin Poulsen, Record "National Security" Surveillance in 2000, SECURITYFocUS, May 2, 2001, at http://www.securityfocus.com/news/201 (citing ADMIN. OFFICE OF THE U.S. COURTS, REPORT OF THE DIRECTOR OF THE ADMINISTRATIVE OfFICE OF THE U.S. COURTS ON APPLICATIONS FOR ORDERS AUTHORIZING OR APPROVING THE INTERCEPTION OF WIRE, ORAL, OR ELECTRONIC COMMUNICATIONS (2001)). 
demanding" FISA methods still sometimes proved to be too much of a burden for agents to apply. The Moussaoui example makes it easy to understand why law enforcement personnel and legislators alike would want to abolish the wall. FISA was designed to create a rapid, efficient, and constitutionally acceptable way of investigating foreign agents, but it evolved into a bureaucratic tangle of formalities and procedures.

Why had FISA spiraled downward in this way? Did the original FISA necessitate the wall procedures, or had they simply been improperly imposed on the statute by the courts and then blindly followed by the DOJ? If the former, then the statute would have to be amended in order to do away with the primary purpose doctrine. If the latter, then the DOJ was free to abolish the wall whenever it wanted.

In what turned out to be a prophetic report issued to Congress in 2000, the National Commission on Terrorism suggested that it was within the DOJ's authority to streamline the foreign intelligence surveillance process, and that such reform was necessary for the country to fend off future terrorist attacks. The Commission concluded that "[ $t]$ he Department of Justice applies [FISA] in a cumbersome and overly cautious manner," and that even though technically under the statute no evidence of wrongdoing or criminal purpose is required to obtain a warrant, in practice the DOJ required such knowledge before permitting an application to proceed to the FISC. $^{92}$ To alleviate this problem, the Commission recommended that " $[t]$ he Attorney General should direct that the Office of Intelligence Policy and Review not require information in excess of that actually mandated by the probable cause standard in the Foreign Intelligence Surveillance Act statute," and that DOJ officials should cooperate with the FBI to ensure more timely review of FISA applications. ${ }^{93}$

But no such changes were made, and as we have seen from the Rowley Memorandum and the reports that support it, complications in the FISA application process may have been one of the reasons the United States failed to prevent the September 11 attacks. One commentator, enraged at the bureaucratic quagmire Rowley described, advocated the "total repeal of FISA," and remarked, "One would think that agents charged with protecting us from a 'dirty nuke' would enjoy the same discretionary search authority as a patrolman who makes a traffic stop. In fact, they have less." 94

The FISA system was the product of a congressional compromise: a balance between preserving defendants' civil liberties and preventing serious crimes perpetrated by foreign powers and their agents. In attempting to fill a void left open by the Supreme Court-which backed away from the

92. NAT'L COMM'N ON TERRORISM, COUNTERING THE CHANGING THREAT OF INTERNATIONAL TERRORISM (2000), available at $\mathrm{http} / / \mathrm{www}$.fas.org/irp/threat/commission.html.

93. Id.

94. Mark Riebling, Uncuff the FBI, WALL ST. J., June 4, 2002, at A20. 
sticky issue of how to regulate the Executive's powers in the foreign affairs arena-FISA and the FISC were never heralded as ideal solutions. But until international terrorism became a clear and present danger to the nation, law enforcement authorities were content to use FISA procedures, even as they became more and more complex with the refinement of the primary purpose doctrine. After September 11, however, lawmakers were no longer able to ignore the fundamental problems with the FISA regime.

\section{HOW THE USA PATRIOT ACT AND IN RE SEALED CASE HARMED THE CONSTITUTIONAL LEGITIMACY OF FISA}

Embedded-some might say hidden-in the USA PATRIOT Act is section 218 , four short lines that dramatically changed the nature of foreign intelligence investigation and prosecution in America. ${ }^{95}$ Under the pre-USA PATRIOT FISA, when a government agent submitted an application for a surveillance order, the executive branch official authorizing the application was required to certify that "the purpose of the surveillance is to obtain foreign intelligence information." 96 Section 218 of the USA PATRIOT Act altered the language of the statute by substituting "a significant purpose" for "the purpose." but also to physical searches of property, which were authorized under FISA amendments passed in $1994 .{ }^{98}$ In effect, this amendment means that the DOJ can now use FISA warrants to pursue nonintelligence evidence to be used in criminal prosecutions. The wall has been torn down.

Undoubtedly, section 218 provides a quick fix to many of the previously articulated problems with FISA procedures. But the amendment creates more problems than it solves. Now that the FISC may consider applications to pursue evidence to be used directly in criminal prosecutions, section 218 has largely removed the unique quality of the cases the FISC considers. In all cases involving potential foreign agents, prosecutors and agents may now make an end run around the normal procedures required to verify probable cause for criminal warrants. As criminal prosecutions based on FISA surveillance increase, a growing number of defendants will be convicted on the basis of evidence procured secretly and without any

95. USA PATRIOT Act, Pub. L. No. 107-56, $\$ 218,115$ Stat. 272, 291 (2001) (to be codified at 50 U.S.C. $\S 1804(\mathrm{a})(7)(B))$. It should be noted that section 218 and many of the other FISA amendments have a four-year sunset provision and will terminate on December 31,2005 , unless renewed. See id $\S 224$. Republican legislators have already begun campaigning to repeal the sunset provisions. See Eric Lichtblau, Republicans Want Terrorism Law Made Permanent, N.Y. TIMES, Apr. 9, 2003, at Bl.

96. Foreign Intelligence Surveillance Act of $1978 \S 104(a), 50$ U.S.C. $\S 1804(a)(7)(B)(2000)$ (amended 2001).

97. USA PATRIOT Act $\S 218$ (to be codified at 50 U.S.C. $\S 1804(a)(7)(B)$ ).

98. See id. 
governmental showing of probable criminal activity. Since FISA applications are typically sealed for security reasons, these defendants will be virtually powerless to challenge the legitimacy of any such evidence.

\section{A. In re All Matters Submitted to the Foreign Intelligence}

\section{Surveillance Court}

The FISC, silent and wholly acquiescent throughout its first twentythree years, finally spoke out on these issues in an opinion written in May 2002 , which was released to the public three months later. ${ }^{99}$ The FISC opinion concerned proposed minimization procedures submitted by the government for use in FISA surveillance operations. As mandated by FISA, each government surveillance request must be accompanied by a minimization plan, directed at reducing the probability that communications involving U.S. persons will be used or distributed if intercepted. ${ }^{100}$ In the minimization procedures at issue, the DOJ gave criminal prosecutors access to "all information developed" through FISA investigations, and authorized prosecutors to "consult extensively and provide advice and recommendations to intelligence officials" concerning "criminal investigation and prosecution as well as the strategy and goals for investigations, the law enforcement and intelligence methods to be used in investigations, and the interaction between intelligence and law enforcement components of investigations.",101 These procedures were a radical departure from previous DOJ wall procedures which prevented prosecutors from supervising and guiding FISA surveillance with an eye toward prosecution. ${ }^{102}$ The DOJ defended its adoption of these new procedures by arguing that section 218 of the USA PATRIOT Act had officially broken down the wall and allowed FISA to be "used primarily for a law enforcement purpose." 103 As further evidence that the wall procedures were a thing of the past, another USA PATRIOT Act amendment to FISA explicitly permitted consultation among federal officers about intelligence information obtained through FISA in order to protect against terrorist attacks. ${ }^{104}$

Despite (and indeed, without extensively commenting on) the USA PATRIOT Act amendments, Judge Lamberth, writing for the en banc FISC,

99. In re All Matters Submitted to the Foreign Intelligence Surveillance Court, $218 \mathrm{~F}$. Supp. 2d 611 (Foreign Intelligence Surveillance Ct. 2002), overruled by In re Sealed Case, 310 F.3d 717 (Foreign Intelligence Surveillance Ct. Review 2002).

100. See 50 U.S.C. $\S \S 1801(\mathrm{~h}), 1805(\mathrm{a})(4)$.

101. 218 F. Supp. $2 d$ at $622-23$.

102. Id. at $619-20$.

103. Id. at 623 (internal quotation omitted).

104. USA PATRIOT Act, Pub. L. No. 107-56, § 504(a), 115 Stat. 272, 364 (2001) (to be codified at 50 U.S.C. $\S 1806(\mathrm{k}))$. 
took issue with and modified these minimization procedures, arguing that they impermissibly contradicted the 1995 DOJ procedures that mandated the wall between prosecutors and investigators. ${ }^{105}$ The court noted: "[T]he collection of foreign intelligence information is the raison d'etre for the FISA... Clearly this Court's jurisdiction is limited to granting orders for ... the collection of foreign intelligence information...."106 But the new procedures, according to the FISC, would cause intelligence investigations to be subordinated to law enforcement objectives, as "criminal prosecutors will tell the FBI when to use FISA (perhaps when they lack probable cause for a Title III electronic surveillance)." 107

Much of this concern was spurred in part by what had become, as the DOJ confessed, a trend of inaccurate and false FISA affidavits from FBI agents, which according to the government resulted from collaboration between agents overseeing intelligence surveillance and agents and prosecutors overseeing criminal investigations of the same targets. ${ }^{108}$ When the government revealed some seventy-five such inaccurate affidavits that were results of breaches of the wall, the FISC established a court rule that required "all Justice Department personnel who received certain FISA information to certify that they understood that under 'wall' procedures FISA information was not to be shared with criminal prosecutors without the Court's approval."109 Given its own institutional commitment to the wall procedures, the FISC rejected the government plan and determined that the procedures were necessary to maintain the integrity of the intelligence-gathering process and of the court itself. The reasoning of the opinion centered on past experience, previous DOJ policy, and the inappropriate nature of the government's altered minimization procedures in light of the primary purpose of FISA. Shying away from the controversial issues underlying the case, the court explicitly declined to rule on the broader-and much more crucial - questions of whether the change in minimization procedures was legally justified by the amendment to FISA effected by section 218 of the USA PATRIOT Act, and whether section 218 itself was constitutional. ${ }^{110}$

105. See 218 F. Supp. $2 d$ at 623.

106. Id. at 613-14.

107. Id. at 624 .

108. Id. at $620-21$ ("In September 2000, the government came forward to confess error in some 75 FISA applications related to major terrorist attacks directed against the United States. The errors related to misstatements and omissions of material facts ...."); see also Lithwick, supra note 65 .

109. 218 F. Supp. $2 d$ at 621.

110. See id. at 615 n.2. 


\section{B. In re Sealed Case}

The government appealed the FISC decision to the Foreign Intelligence Surveillance Court of Review, ${ }^{111}$ which met for the first time in its history to hear the case. The Court of Review came down rather harshly on the lower court, saying that the FISC did "not clearly set forth the basis for its decision," given that its main objection to the minimization procedures was simply their conflict with previous procedures. ${ }^{112}$ The Court of Review also stated that the FISC may well have exceeded its constitutional bounds by unduly interfering with internal DOJ policies and procedures and providing no ostensible constitutional or statutory basis for doing so. ${ }^{113}$ Holding that the FISC's refusal to consider the legitimacy of the primary purpose doctrine itself was error, the court then addressed the DOJ's main arguments: first, that even before the USA PATRIOT Act, the wall requirement was illusory and never had been required by FISA; and second, that even if such a requirement had indeed existed, the USA PATRIOT Act eliminated its relevance. Then, the court considered whether or not the USA PATRIOT Act amendments comported with the requirements of the Fourth Amendment. In a sweeping opinion that contradicted longstanding interpretations of FISA across the circuits, the court questioned the wisdom of the previously entrenched primary purpose doctrine and wall procedures and affirmed the constitutionality of the amended FISA under the Fourth Amendment. This holding is problematic in light of the significant differences between FISC and normal Article III court procedures. In re Sealed Case created a monster court with the right to adjudicate criminal matters in an entirely secret setting, using less stringent standards of probable cause, subject to no public scrutiny or adversary proceedings.

The court's statutory analysis of the issues focused on its claim that the drafters of FISA did not intend to draw a line between intelligence gathering and prosecution. ${ }^{114}$ The legislative history on this issue, however, is far from definitive; even the court acknowledged that support can also be found in the committee reports for the assertion that FISA surveillance was primarily intended for intelligence gathering. ${ }^{115}$

111. See supra note 4 (summarizing the appeals process). 2002).

112. In re Sealed Case, 310 F.3d 717, 721 (Foreign Intelligence Surveillance Ct. Review

113. Id. at 731 .

114. Id. at 724-25 ("'Intelligence and criminal law enforcement tend to merge in this area." (quoting S. REP. NO. 95-701, supra note 43, at 11) (emphasis omitted)). The court omitted the following (and more equivocal) sentence: "The targeting of U.S. persons and the overlap with criminal law enforcement require close attention to traditional Fourth Amendment principles." S. REP. NO. 95-701, supra note 43, at 11.

115. Sealed Case, 310 F.3d at 725. 
Though the Court of Review (perhaps too boldly) alleged that the drafters of FISA had not intended the wall to be an element of FISA in the first place, the DOJ-as well as many circuit and district courts around the nation-had subscribed to the Truong court's primary purpose reasoning from the outset. The wall had been built, if not by Congress, at least by the Executive and the judiciary.

The Eastern District of New York was one of the first courts to apply the Truong reasoning in a case involving a constitutional challenge to FISA surveillance. In United States $v$. Megahey, the court used the plain language of the statute to justify the primary purpose doctrine, pointing out that FISA itself required an executive official to certify that the information sought was "foreign intelligence information" and not evidence intended for criminal prosecution. ${ }^{116}$ As noted by the Court of Review, the First, ${ }^{117}$ Second, ${ }^{118}$ Fourth, ${ }^{119}$ and Eleventh ${ }^{120}$ Circuits all followed the primary purpose doctrine as described in Truong without in-depth discussion of its merits.

Several courts, however, found the wall to be conceptually problematic. In reviewing the Megahey decision, the Second Circuit affirmed the primary purpose doctrine but also noted the practical reality of the situation: "Otherwise valid FISA surveillance is not tainted simply because the government can anticipate that the fruits of such surveillance may later be used ... as evidence in a criminal trial." ${ }^{\text {"2l }}$ Other courts had declined to rule on the primary purpose doctrine in light of this often unavoidable overlap between criminal and intelligence purposes in FISA investigations, especially those concerning international terrorism. ${ }^{122}$

The Court of Review noted that the courts were not in universal agreement on the primary purpose test, and blamed Truong for forcing the government to subscribe to the so-called "false dichotomy" between foreign intelligence information and evidence of criminal activity, when, according to the court, the drafters of the statute had never intended such a result. ${ }^{123}$ The Court of Review asserted that the primary purpose doctrine had become entrenched almost by accident: District and circuit courts had

116. 553 F. Supp. 1180 , 1189 (E.D.N.Y. 1982) (quoting 50 U.S.C. $\S 1804(a)(7)(A)(2000)$ ), aff'd sub nom. United States v. Duggan, 743 F.2d 59 (2d Cir. 1984).

117. See United States v. Johnson, 952 F.2d 565, 572 (1st Cir. 1991).

118. See Duggan, 743 F.2d at 78.

119. See United States v. Pelton, 835 F.2d 1067, 1075-76 (4th Cir. 1987).

120. See United States v. Badia, 827 F.2d 1458, 1464 (11 th Cir. 1987).

121. Duggan, 743 F.2d at 78.

122. See United States v. Sarkissian, 841 F.2d 959, 964-65 (9th Cir. 1988); In re Kevork, 634 F. Supp. 1002, 1015 (C.D. Cal. 1985), aff'd, 788 F.2d 566 (9th Cir. 1986); cf. United States v. Falvey, 540 F. Supp. 1306, 1314 (E.D.N.Y. 1982) (rejecting the Truong test because FISA procedures, when followed, automatically legitimize the warrant, no matter the purpose).

123. In re Sealed Case, 310 F.3d 717, 725, 727 (Foreign Intelligence Surveillance Ct. Review 2002). 
blindly followed Truong (an opinion that did not fully take into account the ramifications of FISA, as its facts occurred before the Act had even been passed), and the DOJ had followed the courts. ${ }^{124}$

Justice Department officials have acknowledged that the wall procedures, instituted formally in July $1995,{ }^{125}$ were followed—often to the detriment of important cases. ${ }^{126}$ Whether or not the primary purpose doctrine was legitimate in the first place, it had evolved into an important part of FISA procedures. What little legislative history there is for the USA PATRIOT Act points to the conclusion that many of the drafters of the law were aware of this reality and intended to alter the traditional patterns of law enforcement and formally break down the wall, as they believed it was harmful to the investigation and prosecution of foreign intelligence cases. The Court of Review cited floor statements from Senators Leahy and Feinstein to this effect. ${ }^{127}$

Despite the apparent jurisprudential and political consensus that the primary purpose doctrine was at least an acceptable interpretation of FISA, the Court of Review questioned the doctrine's fundamental assumptions and condemned it as unworkable. In response to the Truong court's argument that once FISA investigations become criminal, defendants' privacy interests should take priority over foreign policy concerns, the Court of Review emphasized that in many counterintelligence operations, "the government's primary purpose is to halt the espionage or terrorism efforts, and criminal prosecutions can be, and usually are, interrelated with other techniques used to frustrate a foreign power's efforts." 28 The Court of Review went on to point out that the Truong wall between intelligence and prosecution "generates dangerous confusion and creates perverse organizational incentives," and cited the testimony of an FBI agent that the wall may have been a factor in the FBI's failure to prevent the September 11 attacks. ${ }^{129}$

The Court of Review concluded that "even though we agree that the original FISA did not contemplate the 'false dichotomy' [of the primary purpose doctrine], the Patriot Act actually did-which makes it no longer false." 130 The court thus conceded that the primary purpose doctrine had been followed in practice, whether or not the drafters of FISA had intended

124. Id. at 727-28.

125. See In re All Matters Submitted to the Foreign Intelligence Surveillance Court, $218 \mathrm{~F}$. Supp. 2d 611, 619 (Foreign Intelligence Surveillance Ct. 2002), overruled by Sealed Case, 310 F.3d 717.

126. See supra notes $81-91$ and accompanying text.

127. See Sealed Case, 310 F.3d at $732-33$. It is worth considering the possibility that the USA PATRIOT Act was passed with such little deliberation that its drafters never considered carefully whether the wall was a sufficiently entrenched concept to merit its statutory destruction.

128. Id. at 743

129. Id. at 743-44 \& n.29.

130. Id. at 735 . 
this to be the case. But as soon as it acknowledged the existence of the doctrine, the court affirmed its destruction, primarily for practical reasons, citing the difficulties it posed for investigators. ${ }^{131}$ In light of these pragmatic concerns and its previously discussed statutory and jurisprudential analysis, the Court of Review instead counseled the adoption of a wall not between foreign intelligence gathering and prosecution, but between ordinary crimes and foreign intelligence crimes, as the Keith Court had intimated might exist, and as the Court of Review insisted Congress had originally intended to create when it passed FISA. ${ }^{132}$

In so doing, however, the court failed to consider the constitutional justifications that led the Truong court to establish the primary purpose doctrine in the first place. The court did not respond to the Truong Fourth Amendment argument that if criminal and intelligence purposes were to be combined in FISA investigations, regular Article III courts were qualified to be, and indeed should be, the bodies to consider them. In fact, the Court of Review spent very little time considering the constitutionality of the USA PATRIOT Act amendments themselves. Rather, most of the court's opinion focused on the original intent of the FISA drafters and the practical necessities of law enforcement. The court did present a detailed comparison of FISA and Title III warrant procedures, concluding that the two provided virtually equivalent protections to targets. ${ }^{133}$ Still, the court did not go so far as to say that FISA procedures were definitely constitutional under the Fourth Amendment. Instead, it cautiously noted that "to the extent a FISA order comes close to meeting Title III, that certainly bears on its reasonableness under the Fourth Amendment." 134

At the end of its opinion, the court included a brief discussion of the special needs line of search and seizure cases, which justify entirely warrantless searches in "extraordinary situations." 135 Similarly, the court noted that the purpose of FISA-to aid in the protection of the United States from harm at the hands of foreign powers-distinguishes it from the ordinary criminal context. ${ }^{136}$ By juxtaposing post-USA PATRIOT Act FISA with the special needs cases, the court seemed to be hinting that even

131. The Court of Review did acknowledge that it would be unacceptable for the DOJ to use FISA with criminal prosecution as its sole objective, which would be in direct contravention of the statutory language. $I d$. at 735 .

132. Id. at 744 .

133. Id. at 737-42. The Court of Review acknowledged that the standards of probable cause were different, in that FISA did not necessarily require a showing of probable cause of criminal activity for the target. The court concluded that this difference was not material in light of the limited scope of FISA surveillance, which can only be directed at agents of foreign powers, noting that "FISA applies only to certain carefully delineated, and particularly serious, foreign threats to national security." Id. at 739 .

134. Id. at 742 .

135. Id. at 745 .

136. Id. at 746. 
if the new FISA were not legitimate under traditional Fourth Amendment standards, entirely warrantless foreign intelligence searches might find constitutional validation under the special needs doctrine.

At the conclusion of its opinion, the Court of Review revealed its deep uncertainty about the constitutional foundations of its own ruling when it acknowledged that "whether Congress' disapproval of the primary purpose test is consistent with the Fourth Amendment... has no definitive jurisprudential answer," and that even if the USA PATRIOT Act standards "do not meet the minimum Fourth Amendment warrant standards, [they] certainly come close." ${ }^{, 137}$ In effect, the Court of Review held that, one way or another, with or without statutory warrants, foreign intelligence searches were constitutional; to the extent that the new FISA "came close" to both the special needs cases and Title III procedures, it was acceptable. Such a holding is little help to those with a mind to reform the current system-or to those who are unwilling to accept a system that merely comes close to being constitutional.

\section{A PROPOSAL FOR CHANGE}

The USA PATRIOT Act amendments were aimed in part at significantly expanding the government's capacity to effectively investigate and prosecute terrorists under FISA. ${ }^{38}$ But in attempting to strengthen FISA, Congress instead transformed it into a slightly watered-down version of Title III that is, frankly, a conceptual mess. FISA allows warrants to be granted in a hermetically sealed, secret context with a reduced standard of probable cause. ${ }^{139}$ At the same time, despite the government's perfect record, obtaining a FISA warrant is not a piece of cake, largely because of the rigorous process of review that FISA applications are subjected to by DOJ officials. ${ }^{140}$ Once obtained, FISA warrants can now be used primarily

137. Id.

138. Indeed, Attorney General John Ashcroft has noted that the Court of Review's opinion approving the USA PATRIOT Act amendments "revolutionizes our ability to investigate terrorists and prosecute terrorist acts." Linda Greenhouse, Supreme Court Roundup: Opponents Lose Challenge to Government's Broader Use of Wiretaps To Fight Terrorism, N.Y. TIMES, Mar. 25, 2003, at A12.

139. It is important to note that some government officials have alleged that it can be harder to get a FISA warrant than a Title III warrant in some cases, because proving that an individual has ties to a sprawling, amorphous terrorist group like al Qaeda can be more difficult than proving the likelihood that a potential target will commit a crime. See, e.g., Comey Address, supra note 60. But even if a FISA warrant is harder to get than a Title III warrant, the USA PATRIOT Act amendments do make it possible for law enforcement agents to gather evidence for criminal prosecution against someone without any showing that he is associated with criminal activity.

140. Even though such warrants are arguably easier to procure than Title III warrants, it may still be a formidable task for agents to marshal evidence to convince their superiors that a subject is a foreign power or agent thereof, as occurred in the Moussaoui case. See supra notes 88-90 and accompanying text. 
for criminal investigations, as long as a token amount of intelligence surveillance also takes place. The criminal investigations that result can be nearly as sophisticated as those authorized under Title III. ${ }^{141}$

The FISA system that we now have is at the same time too strict and too relaxed. The FISC's secret procedures and altered constitutional standards no longer appear legitimate in light of the avowedly criminal investigations that agents will pursue with FISA warrants. Perhaps if the amended FISA provided extraordinarily effective and rapid ways to crack down on terrorism, we might be more willing to accept its dubious Fourth Amendment constitutionality. But as it stands, many of the pre-USA PATRIOT Act bureaucratic obstacles remain.

Since the Supreme Court has declined to consider the FISA Court of Review decision, at least for the time being, ${ }^{142}$ an institutional response to this constitutional dilemma should be developed. The best course of action, which the Court of Review hinted at near the end of its opinion, is to abandon FISA entirely and return to the days when foreign intelligence surveillance was conducted without warrants and simply subjected to general Fourth Amendment reasonableness principles. This, after all, was the practice America followed for the first fifty years that surveillance technology existed.

\section{A. Case or Controversy?}

At the outset of the discussion of how to reconceptualize foreign intelligence surveillance, it is important to note the fundamental differences between surveillance and garden-variety search and seizure. While search warrants are ordinarily procured after a crime has been committed, surveillance is intended to intercept and prevent crimes while they are in the planning (or even preplanning) stages. Search warrants are initially ex parte, but ultimately discoverable once executed; not so for surveillance orders, which by their very nature must be kept concealed until surveillance has ceased. ${ }^{143}$ The special nature of surveillance is relevant to the debate

141. The USA PATRIOT Act also expanded FBI authority to conduct roving FISA wiretaps, USA PATRIOT Act, Pub. L. No. 107-56, $\$$ 206-207, 115 Stat. 272, 282 (2001) (to be codified at 50 U.S.C. $\S 1805$ ), to utilize pen register and trap and trace orders under FISA, id. $\S \S 214,216$ (to be codified at 18 U.S.C. $\S 3123$ and 50 U.S.C. $\$ 1842$ ), to seize business records under FISA, $i d$. $\S 215$ (to be codified at 50 U.S.C. $\$ 1861$ ), to disclose foreign intelligence information revealed to the grand jury to other federal agencies, id. $\S 203$ (a) (to be codified at FED. R. CRIM. P. 6), and to use "sneak and peek" warrants, id. $\S 213$ (to be codified at 18 U.S.C. $\S 3103$ a), in addition to expanding the scope of Title III to terrorism investigations, id. $\S 201$ (to be codified at 18 U.S.C. $\S 2516)$.

142. The Sealed Case appeal having failed, see supra note 6 , amici are attempting to challenge the constitutionality of the amended FISA in a case in which surveillance has led to an indictment. See United States v. Battle, No. 3:02cr399 (D. Or. filed Oct. 3, 2002).

143. TELFORD TAYLOR, TWO STUDIES IN CONSTITUTIONAL INTERPRETATION 79-85 (1969). 
over the propriety of the USA PATRIOT Act amendments in general: By breaking down the wall between intelligence and criminal investigations, Congress conflated two very different processes that arguably should retain their own procedures.

But the dichotomy between surveillance and searches has greater implications. As Professor Telford Taylor has argued, perhaps surveillance applications should never be considered in any sort of Article III courts, as they are nonadversary steps in the investigative process, inappropriate for judicial disposition. According to this argument, since no case or controversy exists at this stage, courts have no business passing on the legitimacy of surveillance operations until a genuine adversarial dispute is at hand. Taylor suggests that until that point, "[t]he authorization of the judge ... is not an effective screen, and may serve as window-dressing, to relieve the law enforcement official of responsibility for a decision which should be his to make." 144 Under this view, both FISA and Title III warrant procedures are illegitimate assertions of the judicial power in a permanently nonadversarial context. They bury accountability for improper investigations in judicial mystique, which is unconstitutionally applied in the surveillance context when no case or controversy has yet arisen. This is especially true in the FISA setting, where the entire process takes place in secret, and the probable cause standard is greatly attenuated.

The solution, Taylor suggests, is to assign scrutiny of and accountability for surveillance operations primarily to the executive branch-" "to concentrate rather than to diffuse responsibility."145 This of course was the policy the nation followed before Katz, Keith, and Title III transformed the national surveillance landscape. And in the wake of Keith, before FISA was enacted, it appeared that the courts would have no choice but to formulate a workable regime of warrantless foreign intelligence surveillance. The Fourth Circuit took the first stab by articulating the Truong primary purpose test to attempt to confine warrantless investigations to the intelligence context. The D.C. Circuit focused on a way to police abuse of executive discretion. In United States v. Ehrlichman, a case that concerned the criminal liability of those who orchestrated the Watergate break-ins, the court warned: "The danger of leaving delicate decisions of propriety and probable cause to those actually assigned to ferret out 'national security' information is patent, and is indeed illustrated by the intrusion undertaken in this case ..." ${ }^{146}$ For a regime featuring national security surveillance authorized by the executive branch to be constitutionally acceptable, the Ehrlichman court counseled: "[T]he 
personal authorization of the President-or his alter ego for these matters, the Attorney General-is necessary to fix accountability and centralize responsibility for insuring the least intrusive surveillance necessary and preventing zealous officials from misusing the President's prerogative."147 As we have seen, however, instead of adopting the procedure the Ehrlichman court recommended, Congress took action on its own and passed FISA. In so doing, Congress may have neglected to consider the inappropriateness-and possible unconstitutionality-of judicial intervention at the surveillance stage.

In addition to these constitutional concerns, some have argued that the surveillance mechanism is poorly suited to the warrant framework. Professor Akhil Amar has pointed out yet another fundamental difference between searches and surveillance: Search warrants are executed in order to find specific evidence of criminal activity. Surveillance casts a broad net that often yields information that is much more mundane-information that is often voluntarily, if unknowingly, provided by targets. ${ }^{148}$ This is the very same distinction that the Supreme Court made in Olmstead v. United States, when it distinguished wiretapping from forcible search and seizure. ${ }^{149}$ Thus it is possible that the Court got it right the first time it considered the issue of electronic surveillance, in Olmstead. The unique nature of surveillance, as a nonadversarial element of an investigation, may make it inappropriate for the judicial setting in the first place.

As we have seen, FISA is in a state of conceptual and constitutional confusion; the statute is sorely in need of reform. In response to this need, several alternative regimes for foreign intelligence surveillance begin to take shape.

The first option is to do away with FISA altogether and conduct foreign intelligence surveillance proceedings using Title III procedures. The Court of Review did conclude that Title III and FISA procedures were substantially similar; ${ }^{150}$ the natural response to this conclusion is to question the justification for the continued existence of the FISC in the first place. Why not simply collapse FISA procedure into Title III and eliminate the supersecret FISC? As Judge Keith (of the Keith case) himself wrote in a recent opinion, "Democracies die behind closed doors."151 Though this

147. Id.

148. Akhil Reed Amar, Fourth Amendment First Principles, 107 HARV. L. REV. 757, 803 (1994) (citations omitted).

149. See 277 U.S. 438,464 (1928) ("The Amendment itself shows that the search is to be of material things-the person, the house, his papers or his effects."), overruled by Katz v. United States, 389 U.S. 347 (1967), and Berger v. New York, 388 U.S. 41 (1967); see also text accompanying notes 11-13.

150. In re Sealed Case, 310 F.3d 717, 737-42 (Foreign Intelligence Surveillance Ct. Review 2002).

151. Detroit Free Press v. Ashcroft, 303 F.3d 681, 683 (6th Cir. 2002). 
option would not solve the deep problems of the unsuitability of surveillance mechanisms to judicial approval in the first place, at least it would provide for a stronger probable cause standard and a more accessible forum.

As the Keith Court remarked, Article III courts are more than capable of handling the classified information considered by the FISC:

The investigation of criminal activity has long involved imparting sensitive information to judicial officers who have respected the confidentialities involved. Judges may be counted upon to be especially conscious of security requirements in national security cases. . . . Moreover, a warrant application involves no public or adversary proceedings: it is an ex parte request before a magistrate or judge. ${ }^{152}$

Particularly sensitive applications could be considered in camera, and all applications could be sealed until surveillance was complete. The mechanisms of normal Article III courts seem perfectly well suited to handle even the most confidential information.

Additionally, since FISA surveillance appears to be moving out of the intelligence realm and into the criminal arena, the intelligence expertise justification for FISA's lesser probable cause standard and specialized court no longer seems especially compelling. ${ }^{153}$ Indeed, such expertise was likely never a paramount concern. The Keith Court's commentary on this issue is again relevant:

Courts regularly deal with the most difficult issues of our society. There is no reason to believe that federal judges will be insensitive to or uncomprehending of the issues involved in domestic security cases. Certainly courts can recognize that domestic security surveillance involves different considerations from the surveillance of "ordinary crime." If the threat is too subtle or complex for our senior law enforcement officers to convey its significance to a court, one may question whether there is probable cause for surveillance. ${ }^{154}$

If, as the USA PATRIOT Act mandated and the Court of Review confirmed, intelligence gathering no longer need be the primary purpose of

152. United States v. United States Dist. Court, 407 U.S. 297, 320-21 (1972).

153. There may be some value in the centralized, specialized nature of the FISC, but the fact of the matter is that most terrorism cases today are brought in the Southern District of New York and the Eastern District of Virginia, and many of the judges in those districts are just as expert in foreign intelligence matters as FISC judges are.

154. 407 U.S. at 320. 
FISA investigations, then regular Article III courts are more than capable of granting foreign intelligence surveillance warrants.

But such a course of action would doubtless bring a firestorm of protest from the executive branch. The President would contest the imposition of strict judicial supervision over foreign intelligence surveillance, pointing to the Keith decision, along with his constitutionally designated role as Commander in Chief ${ }^{155}$ and the longstanding tradition of deference to the Executive in the realm of foreign affairs and national security. ${ }^{156}$ The Department of Justice would argue that submitting foreign intelligence surveillance to Article III courts would hamstring its investigators in the very area where they need more flexibility, and defeat the purpose of the USA PATRIOT Act amendments. It is thus highly unlikely that legislators would support a proposal to increase the bureaucratic requirements in this context. Additionally, this option presupposes the legitimacy of Title III itself. As discussed above, some would argue that surveillance should be removed from the judicial context entirely-at least until the target has contested it and transformed the issue into an adversary proceeding. These practical and constitutional considerations counsel against a return to Title III.

\section{B. Rediscovering the Benefits of Warrantless Surveillance}

The solution to this dilemma is to adopt a second alternative and return to the jurisprudence that had been chiseled out by the circuit courts before Congress stepped in and passed FISA. The Fourth Amendment has receded into the shadows in recent FISA cases, as compliance with the statute has been taken as the main touchstone of a legitimate search. ${ }^{157}$ But as the Foreign Intelligence Surveillance Court of Review itself acknowledged, the

155. U.S. CONST. art. II, $\$ 2$, cl. 1.

156. See, e.g., Chicago \& S. Air Lines v. Waterman S.S. Corp., 333 U.S. 103, 111 (1948) (noting that "[i]t would be intolerable that courts, without the relevant information, should review and perhaps nullify actions of the Executive taken on information properly held secret," and that foreign affairs issues are "of a kind for which the Judiciary has neither aptitude, facilities nor responsibility"); United States v. Curtiss-Wright Exp. Corp., 299 U.S. 304, 320 (1936) (emphasizing the "very delicate, plenary and exclusive power of the President as the sole organ of the federal government in the field of international relations"); United States v. Clay, 430 F.2d 165,171 (5th Cir. 1970) (urging deference to the executive authority where foreign intelligence secrets are involved), rev'd on other grounds, 403 U.S. 698 (1971); see also William C. Banks \& M.E. Bowman, Executive Authority for National Security Surveillance, 50 AM. U. L. REV. 1 (2000); Saikrishna B. Prakash \& Michael D. Ramsey, The Executive Power over Foreign Affairs, 111 YALE L.J. 231 (2001).

157. See, e.g., United States v. Squillacote, 221 F.3d 542, 554 (4th Cir. 2000); United States v. Isa, 923 F.2d 1300, 1304 (8th Cir. 1991); Global Relief Found., Inc. v. O'Neill, 207 F. Supp. 2d 779,790 (N.D. Ill.), aff'd, 315 F.3d 748 (7th Cir. 2002), petition for cert. filed, 72 U.S.L.W. 3092 (U.S. July 3, 2003) (No. 03-46). 
statute has changed, and its constitutional foundations are shaky; ${ }^{158}$ reliance on the terms of the statute alone is not likely to guarantee that targets' civil liberties are preserved. Faced with this situation, the Court of Review did not certify the constitutionality of FISA on its own terms. Rather, it rejected the Truong line of cases, which had painstakingly established the wall between foreign intelligence and criminal investigations, and attempted to justify the amended FISA procedures as roughly equivalent to those of Title III, while simultaneously insisting on the distinctiveness of FISA investigations. ${ }^{159}$ This constitutional patchwork likely will not stand the test of time. The wiser course of action is to repeal FISA and return to a regime of warrantless foreign intelligence surveillance.

Under such a system, the government would not be required to procure a judicial warrant before conducting surveillance of foreign powers and their agents, but targets could challenge the reasonableness of the surveillance in an adversary proceeding in an Article III court after the surveillance was complete. In this regime, government action would still be subject to the basic protections of the Fourth Amendment prohibiting unreasonable searches; indeed, when considered in normal Article III courts, such protections would likely end up being stronger than those currently provided under the amended FISA. Signaling that reasonableness is perhaps the most appropriate polestar for judging Fourth Amendment constitutionality, the Foreign Intelligence Surveillance Court of Review ended up affirming the constitutionality of the amended FISA because "the surveillances it authorizes are reasonable." 160

A wholly unregulated system of surveillance would be a hard sell to legislators and citizens alike, since most Americans are accustomed to reliance on the supposed protections of the warrant procedure, whether those protections are effective in practice or not. Additionally, the nation has tried warrantless foreign intelligence surveillance before with no success, as the Church Committee findings made clear. ${ }^{161}$ But now that the FISA framework has crumbled, we are charged with devising a modern framework for warrantless foreign intelligence surveillance that will preserve the civil liberties of targets. This task is especially challenging given the top-secret nature of many foreign intelligence investigations.

158. See In re Sealed Case, 310 F.3d 717, 746 (Foreign Intelligence Surveillance Ct. Review 2002).

159. See id. at $737-42$.

160. Id. at 746.

161. See supra text accompanying note $40-41$. 


\section{The Traditional Reasonableness Standard}

Prominent constitutional historians have concluded that a regime of warrantless searches is actually the most faithful interpretation of the Fourth Amendment, as the Framers intended it. In early America, it was not the absence of warrants that citizens protested, but overreaching, general warrants used as instruments for intrusive and abusive official searches. ${ }^{162}$ When they wrote the Fourth Amendment, the Founding Fathers thus aimed at both preventing "unreasonable" searches and seizures, ${ }^{163}$ and guarding against general warrants, issued without sufficient basis and capable of being used to wreak significant havoc. The Framers did not intend warrants to be prerequisites for reasonable searches, but rather the warrant was nearly universally treated as "an enemy, not a friend." 164 The very phrasing of the Fourth Amendment ("no warrants shall issue") indicates the negative popular sentiment toward warrants. ${ }^{165}$ As Professor Amar has pointed out, a plain reading of the text of the Fourth Amendment supports this historical reading: The Reasonableness Clause and the Warrant Clause are separate and distinct from one another. For a search to be reasonable, the language of the Constitution does not require the procurement of a warrant. ${ }^{166}$

Though this historical and textual analysis may be persuasive, the courts by and large have insisted on adhering to the "warrant requirement" that developed during the course of the twentieth century. ${ }^{167}$ The Keith Court itself adhered to this formula as it ruled that a warrant was required for domestic security surveillance. There, the Court affirmed that " $[t]$ he warrant clause of the Fourth Amendment is not dead language," and is a necessary component of a constitutional search. ${ }^{168}$ Part of the Court's justification for this holding was that the exceptions to the "warrant requirement" were "few in number and carefully delineated."169 Notably, the force of this reasoning has certainly declined since Keith. There are currently more than twenty exceptions to the probable cause standard, the warrant requirement, or both. ${ }^{170}$ As Professor Amar has commented, "Warrants are not required-unless they are. All searches and seizures must

162. TAYLOR, supra note 143 , at 41.

163. U.S. CONST. amend. IV.

164. TAYLOR, supra note 143 , at 41.

165. See AKHIL REEd AMAR, THE BILl OF RIGHTS 69 (1998).

166. See Amar, supra note 148 , at 761 .

167. See supra text accompanying notes 10-24; see also Camara v. Mun. Court, 387 U.S. $523,528-29$ (1967) ("[O]ne governing principle, justified by history and by current experience, has consistently been followed: except in certain carefully defined classes of cases, a search of private property without proper consent is 'unreasonable' unless it has been authorized by a valid search warrant.").

168. United States v. United States Dist. Court, 407 U.S. 297, 315 (1972).

169. Id. at 318.

170. See Craig M. Bradley, Two Models of the Fourth Amendment, 83 MiCH. L. REV. 1468, 1473-74 (1985) (listing exceptions). 
be grounded in probable cause-but not on Tuesdays. And unlawfully seized evidence must be excluded whenever five votes say so." ${ }^{171}$ Justice Scalia has written that the "'warrant requirement' [is] so riddled with exceptions that it [is] basically unrecognizable," 172 advocating a return to a general reasonableness standard for Fourth Amendment cases. ${ }^{173}$

In addition, the burgeoning line of "special needs cases" has signaled the Supreme Court's increased willingness to forego the "warrant requirement," the probable cause standard, and the individualized suspicion paradigm, and to conduct a reasonableness analysis in cases where important governmental interests are at stake. ${ }^{174}$

The so-called warrant requirement has been eviscerated over the past half-century to the point where its application is far from consistent or predictable. A move to a general reasonableness standard would free judges from a complex and tangled web of precedents and provide them with a more faithful way of applying the Constitution.

\section{Reasonableness in the Foreign Intelligence Surveillance Context}

In light of the problems with warrant procedures in the foreign intelligence context, this area of the law is particularly ripe for a reasonableness regime. If such a framework were applied in these cases, instead of questioning the fidelity of the surveillance to a complex and contradictory statutory scheme in an ex parte setting, judges would be assessing contested surveillance on its own terms as part of an adversary proceeding. They would then be able to fulfill their constitutional duties as Article III judges and hold law enforcement conduct to the standard the Framers intended in the first place- - one of constitutional reasonableness.

The foreign intelligence context is well suited to a warrantless regime for a number of reasons. The DOJ has proven itself to be more than capable of implementing stringent internal review processes to guarantee that the only surveillance operations conducted are those for which there are excellent reasons. Removing the FISC from the process would allow the DOJ to move more quickly when time is of the essence, and give law

171. Amar, supra note 148 , at $757-58$.

172. California v. Acevedo, 500 U.S. 565, 582 (1991) (Scalia, J., concurring).

173. Id. at 584 (Scalia, J., concurring).

174. There are dozens of cases in which the Supreme Court has declared warrantless searches justified by special governmental needs. See, e.g., Mich. Dep't of State Police v. Sitz, 496 U.S. 444 (1990) (upholding highway sobriety checkpoints); United States v. Martinez-Fuerte, 428 U.S. 543 (1976) (upholding warrantless border searches for illegal aliens). The Court has declined to uphold such searches in cases where the primary purpose relates to general crime control interests. See Ferguson v. City of Charleston, 532 U.S. 67 (2001); City of Indianapolis v. Edmond, 531 U.S. 32 (2000). The latter cases arguably would not apply in the foreign intelligence context, since the Executive traditionally enjoys more expansive autonomy in foreign and military matters than in routine law enforcement. 
enforcement authorities more latitude in choosing their initial targets, since they would not have to formally establish probable cause that the target was an agent of a foreign power. At the same time, the possibility of after-thefact reasonableness review of the merits of their decisions in Article III courts (in camera or not) would help to guarantee calm and careful DOJ decisionmaking. As a further safeguard against executive abuse of warrantless surveillance authority, the Attorney General and the head of the authorizing agency would each be required to sign off on all surveillance operations, as they currently are under FISA, which would guarantee personal and political accountability for any inappropriate surveillance. Public accountability would play a greater role than it currently does under FISA, as these two political figures alone would bear the burden of certifying that all searches were reasonable; there would be no judicial involvement to spread the blame. ${ }^{175}$ Additionally, in order to provide teeth to the accountability mechanism, the DOJ would be required to report all ongoing foreign intelligence surveillance operations to the House and Senate Intelligence Committees, which would be authorized to investigate and publicly comment on any such investigations they found objectionable.

Removing the courts from the secret surveillance context is also desirable from a constitutional standpoint: In a reasonableness regime, no court would be required to assess an ex parte order that contemplated a search of someone who had not been accused of any crime, so there would be no case or controversy issue. Furthermore, the supersecret FISC would be eliminated entirely; even though no court has declared its procedures unconstitutional, there is something troubling about an Article III court making important rulings, concealed from all forms of public scrutiny.

The aforementioned "special needs" doctrine might be an ideal way to ease into a post-FISA warrantless surveillance regime. Without using the terminology of "special needs," circuit courts deciding foreign intelligence cases after Keith and before FISA formulated just such a standard when they balanced the privacy interests of individuals being investigated against the strong governmental interest in countering foreign threats to national security. ${ }^{176}$ Returning to this paradigm and integrating it into the modern special needs framework would make what was old new again, and provide a ready mechanism to abandon the warrant requirement for foreign intelligence surveillance, leaving the FISA regime behind.

Though the foreign intelligence arena is badly in need of such a radical change, certain features of sensitive surveillance cases complicate the traditional reasonableness paradigm. As the D.C. Circuit noted in the

176. See supra notes 29-39 and accompanying text. 
Ehrlichman case ${ }^{177}$ and as Justice Douglas warned in his Katz concurrence, ${ }^{178}$ if the executive branch is to be given expansive authority to investigate criminal activity, some sort of safety net must be in place to guard against abusive conduct. When proposing a reasonableness standard for normal searches and seizures, Professor Amar suggested policing the abuse of the warrantless regime by allowing defendants to file $\S 1983$ or Bivens actions for damages against government entities whose employees abused their discretion and acted unreasonably. ${ }^{179}$ But such an enforcement mechanism would be more difficult in the foreign intelligence surveillance context, where many investigations have to be kept sealed for security reasons. Surveillance targets might never know that they had been investigated until they were indicted, and even then the government might make a convincing case not to disclose the justifications for the surveillance in open court. ${ }^{180}$ Or, perhaps worse yet, innocent targets might be surveilled without any prior judicial approval, never be charged, and never have any knowledge that their privacy had been violated. ${ }^{181}$

One possible way to modify the reasonableness standard to fit the foreign intelligence context would be to require law enforcement authorities to provide notice to every surveillance target once the investigation is complete. Then, each target would have the option of challenging the reasonableness of such surveillance in an Article III court through a Bivens action. The judge would then conduct a normal Fourth Amendment analysis of the circumstances of the surveillance undertaken. As there would be no FISA warrant, there would be no sealed FISA application hidden from the target, so if and when the government wished to conceal sensitive

177. United States v. Ehrlichman, 546 F.2d 910, 926 (1973); see also supra text accompanying notes 146-147.

178. Katz v. United States, 389 U.S. 347, 360 (1967) (Douglas, J., concurring); see also supra text accompanying note 24 .

179. See Amar, supra note 148 , at 812-13.

180. This happens under the current system as well. In United States v. Squillacote, 221 F.3d 542 (4th Cir. 2000), a husband and wife were surveilled for 550 days under twenty separate FISA orders. They were convicted of conspiring to commit espionage and sentenced to seventeen and twenty-two years in prison, respectively, almost exclusively on the basis of the information gleaned from the FISA warrants. Pentagon Lawyer and Husband Sentenced for Espionage, CNN, Jan. 22, 1999, at http://www.cnn.com/US/9901/22/spies.sentenced. Despite the best efforts of their attorneys, however, the court never permitted them to see any of the government's FISA applications, as the government had claimed they were sensitive documents, protected under 50 U.S.C. $\S 1806(f)$, which allows the district judge to deprive defendants of access to FISA applications for security reasons. Squillacote, 221 F.3d at 553-54. See also United States v. Battle, No. 3:02 cr399 (D. Or. filed Oct. 3, 2002), discussed supra notes 62 and 142, where defendants are alleging that Article III courts should have expanded ability to review FISA orders, and that $\S$ $1806(\mathrm{f})$ violates their due process rights.

181. It is important to note that this could also happen to a target of a Title III search, since the USA PATRIOT Act eliminated the requirement of mandatory notice for targets of "sneak and peek" warrants, which allow law enforcement agents to search an area frequented by the target in the target's absence without his or her knowledge. See USA PATRIOT Act, Pub. L. No. 107-56, § 213,115 Stat. 272,286 (2001) (to be codified at 18 U.S.C. $\S 3103 a$ ). 
information about the search, it would have to approach the judge and justify the reasons for such concealment. ${ }^{182}$ Such stricter scrutiny of what should be classified would likely lead to greater openness and more extensive opportunities for targets, both criminal defendants and innocent victims alike, to challenge the reasonableness of warrantless searches involving them. A problem with this proposal is that some warrantless surveillance operations would likely go on for years, and targets would have no opportunity to challenge them until the invasion of privacy involved had become enormous. But such is the fundamental nature of surveillance-it cannot succeed if the target is aware that it is occurring. Thus, it is better to provide the target with some substantive mechanism for challenging the Fourth Amendment reasonableness of the surveillance than virtually none at all, which is the current state of affairs.

\section{Applying the Standard}

It is important to keep in mind that if courts were to move to a general reasonableness standard for the consideration of foreign intelligence surveillance, some sort of consensus among the political branches would have to be reached on the appropriate meaning of reasonableness. Congress would have to acquiesce and trust in the reasonableness framework enough to repeal FISA. The executive branch would be charged with all preliminary determinations of reasonableness as it conducted warrantless investigations. Congressional Intelligence Committees would be obligated to object to unreasonable DOJ surveillance operations. When defendants and targets challenged surveillance, the judicial branch would be asked to apply its own conception of common sense and constitutional reason to the situation, and provide the final word on the reasonableness of surveillance. In such a regime, individuals at all phases of the system would be required to consider and interpret the Fourth Amendment. Such continuous and searching constitutional thought might well bring added legitimacy to the foreign intelligence surveillance case law.

Of course, judges often differ in their opinions; a morass of inconsistent reasonableness precedents could conceivably arise, complex enough to rival the current catalog of exceptions to the warrant requirement. Reasonableness is a complex concept not readily boxed in, but it is a term no more difficult to construe than any other in the Constitution. Our courts

182. In the current system, there is almost no opportunity for substantive, public review of the circumstances of the FISA search. According to the Eastern District of Virginia, "[T]his Court knows of no instance in which a court has required an adversary hearing or disclosure in determining the legality of a FISA surveillance. To the contrary, every court examining FISAobtained evidence has conducted its review in camera and ex parte." United States v. Nicholson, 955 F. Supp. 588, 592 (E.D. Va. 1997). 
were created to help guide our endeavors to understand these words. When a statutory regime is failing, better that we leave it behind, return directly to the document the Framers handed us, and charge our judges with adapting their words to our modern circumstances. Indeed, the Keith Court may already have provided us with the starting point for this inquiry: Reasonableness in the context of surveillance should be determined by balancing individual privacy interests against the government's need to fulfill its duty to protect the citizenry. ${ }^{183}$

\section{CONCLUSION}

In advocating for the repeal of FISA and the adoption of a reasonableness standard in the consideration of foreign intelligence surveillance cases, it may be instructive to consider a recent case where such a calculus was actually utilized, and resulted in a thoughtful, wellreasoned decision. In United States $v$. Bin Laden, ${ }^{184}$ several defendants were charged with the bombing of U.S. embassies in Kenya and Tanzania, and protested the warrantless surveillance of the Kenya home of defendant Wadih El-Hage, an American citizen. The court ultimately ruled that the Fourth Amendment contained an exception for foreign intelligence searches performed overseas. FISA did not apply, as by its terms the statute's reach is confined to searches conducted within the United States. ${ }^{185}$ Thus, the court was left with a clean slate on which to consider the issue of the legitimacy of warrantless foreign intelligence surveillance, uncomplicated by the complex statutory framework of FISA. The court chose to abandon the warrant requirement in the overseas context and to conduct a reasonableness analysis instead. In a discussion of the "costs of imposing a warrant requirement," 186 the court mentioned the Truong and Keith admonitions that a warrant requirement might " unduly frustrate the efforts of Government to protect itself from acts of subversion and overthrow directed against it." 187 The court also noted the special needs cases in support of its assertion that a warrant requirement would be an "undue burden" in the context of foreign intelligence searches abroad, ${ }^{188}$ and cast doubt on the institutional competence of the judiciary to supervise investigations in such cases. ${ }^{189}$

183. United States v. United States Dist. Court, 407 U.S. 297, 314-15 (1972).

184. 126 F. Supp. 2d 264 (S.D.N.Y. 2000).

185. Id at $274-75$.

186. Id. at 273-75.

187. Id. at 274 (quoting United States v. United States Dist. Court, 407 U.S. at 315 ).

188. Id.

189. See id. 
In light of these considerations, the court formulated an exception to the warrant requirement, "narrowly drawn" to cover only overseas searches. ${ }^{190}$ Notably, the court also built a primary purpose test into its framework, citing Truong and United States $v$. Butenko to emphasize that such surveillance would be illegal if unrelated to the "foreign affairs needs of a President." 191 Having returned to pre-FISA case law to form the basis of its ruling, the court then used a Fourth Amendment reasonableness analysis to consider the defendant's claim that the electronic surveillance of his home was of such a long duration as to be unreasonable. Inquiry into the specific facts and circumstances of the case, informed by the relevant precedents, led the court to conclude that the surveillance was reasonable. ${ }^{192}$

The Bin Laden court may have struck a visionary pose when it decided to favor a regime of warrantless searches policed by Fourth Amendment reasonableness analysis. Such a policy has the potential to improve the current state of affairs for all parties involved. Law enforcement authorities would have greater flexibility and freedom to pursue foreign intelligence investigations. At the same time, a renewed focus on Fourth Amendment principles would potentially increase protection of the civil liberties of surveillance targets.

Perhaps unknowingly, the DOJ may already be pushing domestically conducted foreign intelligence operations in the direction of warrantless surveillance. FISA contains an exception allowing the Attorney General to authorize foreign intelligence surveillance for up to seventy-two hours without FISC approval in an emergency situation. ${ }^{193}$ This time period was increased from twenty-four hours in the wake of September 11. ${ }^{194}$ Attorney General John Ashcroft recently revealed to Congress that he approved more than 170 such warrants in 2002, three times the number used throughout the entire previous twenty-three years. ${ }^{195}$ Ashcroft commented that the DOJ's increased usage of emergency FISA procedures is one of the reasons there have been no further terrorist attacks in America since September 11. ${ }^{196}$

Ashcroft's comment supports the contention that a warrant-free procedure might allow for increased law enforcement effectiveness. At the same time, if such surveillance were conducted without complex, secret FISA procedures at their roots, targets would be better able to challenge them after the fact in normal Article III courts on Fourth Amendment

190. Id. at 277 .

191. Id. at 278 (quoting United States v. Butenko, 494 F.2d 593, 606 (3d Cir. 1974)).

192. See id. at 285-86.

193. See Intelligence Authorization Act for Fiscal Year 2002, Pub. L. No. 107-108, § 314(a)(2)(B), 115 Stat. 1394, 1402 (2001) (to be codified at 50 U.S.C. $\$ 1805(\mathrm{f})$ ).

194. See id.

195. Ashcroft Accelerates Use of Emergency Spy Warrants, CNN, Mar. 24, 2003, at http://www.cnn.com/2003/LAW/03/24/spy.powers.ap.

196. Id. 
reasonableness grounds. The repeal of FISA, though it sounds dramatic, would not be a drastic change. It would simply effectuate the nation's return to its previous tradition of executive discretion in foreign affairs, while at the same time allowing normal Article III courts to reclaim their rightful role in adjudicating the Fourth Amendment reasonableness of foreign intelligence and criminal surveillance. The struggle between executive discretion and individual liberties has long plagued the foreign intelligence surveillance debate. As justification for executive authority in this regard, some have cited the Machiavellian idea that "at times it is necessary to do admittedly evil things for the preservation and welfare of the political community." 197 We need not be obliged, however, to do evil in order to protect ourselves from foreign threats; instead, we need only return to the text and fundamental principles of the Fourth Amendment, allowing the Constitution both to safeguard the liberties of criminal defendants and to guide law enforcement agents in their efforts to protect the nation from harm.

197. Martin S. Sheffer, Nixon, Mitchell, and Warrantless Wiretaps: A Presidential Attempt To Suspend the Fourth Amendment, 16 OHIO N.U. L. REV. 637, 660 (1989); see also Niccolo MACHIAVELLI, THE PRINCE 67 (Angelo M. Codevilla ed. \& trans., Yale Univ. Press 1997) (1532) ("[A] prince . . . cannot observe all those things by which men are considered good, it often being necessary to maintain the state, to operate against faith, against charity, against humaneness, against religion. And therefore it is necessary ... not to depart from good when he can, but to know how to enter into evil when he needs to."). 
Imaged with the Permission of Yale Law Journal 